\title{
In vivo production of prostacyclin and thromboxane in patients with acute myocardial infarction
}

\author{
P HENRIKSSON, Å WENNMALM, O EDHAG, O VESTERQVIST, * K GREEN* \\ From the Department of Medicine, Huddinge Hospital, and ${ }^{\star}$ Department of Clinical Chemistry, Karolinska \\ Hospital, Stockholm, Sweden
}

SUMMARY The in vivo production of prostacyclin and thromboxane was monitored by measuring their major urinary metabolites 2,3-dinor-thromboxane $\mathrm{B}_{2}$ and 2,3-dinor-6-ketoprostaglandin $F_{1 \alpha}$ in ten patients with acute myocardial infarction, five on standard treatment and five receiving prostacyclin infusion. During acute myocardial infarction excretion of 2,3-dinor-thromboxane $\mathbf{B}_{2}$ and 2,3-dinor-6-keto-prostaglandin $F_{1 \alpha}$, measured by a gas chromatography-mass spectrometry method with deuterated internal standards, was significantly increased. This indicates that thromboxane and prostacyclin synthesis are increased during the development of acute myocardial infarction. The excretion data for 2,3-dinor-thromboxane $\mathbf{B}_{2}$ showed that after administration of aspirin there was less pronounced and more variable inhibition than expected. Prostacyclin infusion did not markedly affect the excretion of the thromboxane metabolite.

There has been considerable interest in the possible role of platelets in the pathogenesis of acute myocardial infarction. ${ }^{1}$ The discovery of thromboxane $A_{2}$ and its vasoconstricting and platelet aggregating effects has focused attention on the possible involvement of this platelet-derived compound in cardiovascular disease. ${ }^{2}$ Similarly the discovery of prostacyclin and its vasodilatory and platelet antiaggregatory effects triggered off intense research on the possible role of this compound in protective mechanisms against cardiovascular disease. ${ }^{3}$

Studies on the possible involvement of those compounds in human cardiovascular disease have long been hampered by the lack of suitable methods for monitoring the in vivo production of thromboxane $A_{2}$ and prostacyclin. Thromboxane $A_{2}$ and prostacyclin are chemically degraded in vivo to thromboxane $B_{2}$ and 6-keto-prostaglandin $F_{1 \alpha}$ respectively. It is highly questionable, however, whether measurement of thromboxane $B_{2}$ in blood reflects thromboxane $\mathrm{A}_{2}$ synthesis in vivo. ${ }^{4}$ Increasing evidence also suggests that concentrations of 6-keto-prostaglandin $F_{1 \alpha}$ found in samples of peripheral blood do not reflect the formation of prostacyclin in vivo. ${ }^{5-8}$

Requests for reprints to Dr P Henriksson, Department of Medicine, Huddinge Hospital, S-141 86 Huddinge, Sweden.

Accepted for publication 25 October 1985
The in vivo metabolism of thromboxane $B_{2}$ and prostacyclin has been studied in man and the main urinary metabolites have been identified as 2,3-dinor-thromboxane $B_{2}$ and 2,3-dinor-6-ketoprostaglandin $F_{1 \alpha}$ respectively. ${ }^{910}$ Methods for analysis of these compounds have been developed based on deuterated internal standards/carriers and gas chromatography-mass spectrometry. ${ }^{11-14}$ Excretion of those metabolites quickly (0.5-1.5 hours) and adequately reflects changes in the production of thromboxane $A_{2}$ and prostacyclin in vivo. ${ }^{74-16}$ The intra-individual variation in the excretion of these metabolites is small and independent of urine production. ${ }^{16}$ The excretion of the prostacyclin metabolite is, however, considerably increased by physical exercise. ${ }^{14}$

We report on the formation of thromboxane $A_{2}$ and prostacyclin in vivo during and after the development of myocardial infarction. ${ }^{17}$

\section{Patients and methods}

All patients were admitted to the coronary care unit less than seven hours after the onset of chest pain. A diagnosis of myocardial infarction was confirmed by creatine kinase $\mathrm{MB}$ estimations every four hours. Five patients were given placebo infusion and five had prostacyclin infusion (4-5 ng/ $/ \mathrm{kg} / \mathrm{min}$ ) for 96 hours as well as conventional treatment. ${ }^{18}$ Urine was 
collected continuously before and every eight hours during the infusion period and was analysed for 2,3-dinor-thromboxane $B_{2}$ and 2,3-dinor-6-ketoprostaglandin $\mathrm{F}_{1 \alpha}$. This design was selected in order to study not only the magnitude but also the dynamics of the synthesis of thromboxane and prostacyclin. A 12 hour urine collection was obtained from most individuals seven to nine months after the acute myocardial infarction.

The methods that we used to measure 2,3-dinor-thromboxane $B_{2}$ and 2,3-dinor-6-ketoprostaglandin $F_{1 \alpha}$ in urine have been described in detail elsewhere. ${ }^{1314}$

\section{Results}

The Table shows the results from the initial chest $x$ ray investigation as well as the medication given to each individual as a result of the clinical decision reached during the first three days after admission. All patients were given $0.5 \mathrm{~g}$ of aspirin and $225 \mathrm{mg}$ dipyridamole 72 hours after the start of the infusion as a part of the study protocol. Figure 1 shows the urinary excretion of 2,3-dinor-thromboxane $B_{2}$ and 2,3-dinor-6-keto-prostaglandin $F_{1 \alpha}$ from the five patients (cases A-E) on placebo infusion and Fig. 2 their excretion from patients $(F-J)$ on prostacyclin. The excretion rate of 2,3-dinor-thromboxane $\mathbf{B}_{2}$ and 2,3-dinor-6-keto-prostaglandin $F_{1 \alpha}$ in normal healthy individuals is $130-535 \mathrm{pg} / \mathrm{mg}$ creatinine and $38-508 \mathrm{pg} / \mathrm{mg}$ creatinine respectively. ${ }^{1314}$ Descrip- tions of the individual cases are given below. Apart from aspirin none of the conventional drugs (such as morphine and frusemide) that were given affected the excretion of the thromboxane and prostacyclin metabolites.

Patient $A$-The initial excretion of 2,3-dinorthromboxane $\mathrm{B}_{2}$ was clearly higher than that seen in normal males. The patient received $500 \mathrm{mg}$ of aspirin because of pain 9,15 , and 22 hours after the start of infusion. This reduced the excretion of 2,3-dinor-thromboxane $\mathbf{B}_{2}$ by about half to $378 \mathrm{pg} / \mathrm{mg}$ creatinine. Another dose of $500 \mathrm{mg}$ aspirin at $69 \mathrm{~h}$ caused a further reduction from 205 to $124 \mathrm{pg} / \mathrm{mg}$ creatinine. Urinary excretion of 2,3-dinor-6-keto-prostaglandin $F_{1 \alpha}$ was initially within the limits for normal healthy males, but there was a continuous increase in concentrations up to $3110 \mathrm{pg} / \mathrm{mg}$ creatinine from seven to 15 hours after the maximum creatine kinase $\mathrm{MB}$ concentration.

Patient $B$-Before and during the tirst 2.5 days of infusion urinary excretion of 2,3-dinor-thromboxane $B_{2}$ was two to four times higher than the highest excretion seen in normal healthy females. Sixty one hours after the start of the infusion she was given $500 \mathrm{mg}$ of aspirin, and 4-12 hours afterwards excretion of 2,3-dinor-thromboxane $B_{2}$ increased to $5646 \mathrm{pg} / \mathrm{mg}$ creatinine. This patient initially had normal urinary excretion of 2,3-dinor-6-ketoprostaglandin $\mathrm{F}_{1 \alpha}$ that later increased to a peak of $3605 \mathrm{gg} / \mathrm{mg}$ creatinine. Nine months later excretion of 2,3-dinor-thromboxane $B_{2}$ and 2,3-dinor-6-keto-

Table Medication in study group

\begin{tabular}{|c|c|c|c|c|}
\hline $\begin{array}{l}\text { Case } \\
\text { No }\end{array}$ & Initial chest $x$ ray findings & Day 1 & Day 2 & Day 3 \\
\hline $\mathbf{A}$ & Congestive heart failure & $\begin{array}{l}\text { Morphine } 28 \mathrm{mg} \text { iv, } \\
\text { practolol } 2 \mathrm{mg} \text { iv, } \\
\text { frusemide } 120 \mathrm{mg} \text { iv, } \\
\text { aspirin } 1.5 \mathrm{~g} \text { oral }\end{array}$ & Frusemide $80 \mathrm{mg}$ oral & Frusemide $80 \mathrm{mg}$ oral \\
\hline B & Normal & $\begin{array}{l}\text { Morphine } 17.5 \mathrm{mg} \text { iv, } \\
\text { frusemide } 120 \mathrm{mg} \text { iv }\end{array}$ & Morphine $5 \mathrm{mg}$ iv & Metoprolol $150 \mathrm{mg}$ oral \\
\hline $\begin{array}{l}\text { C } \\
\text { D }\end{array}$ & $\begin{array}{l}\text { Normal } \\
\text { Normal }\end{array}$ & $\begin{array}{l}\text { Pethidine } 25 \mathrm{mg} \text { iv, } \\
\text { frusemide } 20 \mathrm{mg} \text { iv }\end{array}$ & $\begin{array}{l}\text { Metoprolol } 150 \mathrm{mg} \text { oral } \\
\text { Metoprolol } 150 \mathrm{mg} \text { oral }\end{array}$ & $\begin{array}{l}\text { Metoprolol } 150 \mathrm{mg} \text { oral } \\
\text { Metoprolol } 150 \mathrm{mg} \text { oral }\end{array}$ \\
\hline$\underset{\mathbf{F}}{\mathbf{F}}$ & $\begin{array}{l}\text { Enlarged } \\
\text { Enlarged }\end{array}$ & $\begin{array}{l}\text { Morphine } 10 \mathrm{mg} \text { iv } \\
\text { Morphine } 20 \mathrm{mg} \text { iv, } \\
\text { frusemide } 20 \mathrm{mg} \text { iv, } \\
\text { metoprolol } 200 \mathrm{mg} \text { oral }\end{array}$ & $\begin{array}{l}\text { Metoprolol } 100 \mathrm{mg} \text { oral } \\
\text { Metoprolol } 200 \mathrm{mg} \text { oral }\end{array}$ & $\begin{array}{l}\text { Metoprolol } 100 \mathrm{mg} \text { oral } \\
\text { Metoprolol } 200 \mathrm{mg} \text { oral }\end{array}$ \\
\hline $\mathbf{G}$ & Congestive heart failure & $\begin{array}{l}\text { Morphine } 18 \mathrm{mg} \text { iv, } \\
\text { frusemide } 80 \mathrm{mg} \text { iv }\end{array}$ & $\begin{array}{l}\text { Morphine } 20 \mathrm{mg} \text { iv, } \\
\text { aspirin } 8 \mathrm{~g} \text { oral, } \\
\text { hydrocortisone } 100 \mathrm{mg} \text { iv, } \\
\text { metoprolol } 150 \mathrm{mg} \text { oral }\end{array}$ & $\begin{array}{l}\text { Aspirin } 8 \mathrm{~g} \text { oral, } \\
\text { metoprolol } 150 \mathrm{mg} \text { oral }\end{array}$ \\
\hline $\mathbf{H}$ & Congestive heart failure & $\begin{array}{l}\text { Morphine } 38 \mathrm{mg} \text { iv, } \\
\text { frusemide } 80 \mathrm{mg} \text { iv }\end{array}$ & $\begin{array}{l}\text { Frusemide } 40 \mathrm{mg} \text { oral, } \\
\text { atenolol } 100 \mathrm{mg} \text { oral, } \\
\text { aspirin } 1.5 \mathrm{~g} \text { oral }\end{array}$ & $\begin{array}{l}\text { Frusemide } 40 \mathrm{mg} \text { oral, } \\
\text { atenolol } 100 \mathrm{mg} \text { oral, } \\
\text { aspirin } 1.5 \mathrm{~g} \text { oral }\end{array}$ \\
\hline I & Congestive heart failure & $\begin{array}{l}\text { Pethidine } 25 \mathrm{mg} \text { iv, } \\
\text { ketobemidone } 10 \mathrm{mg} \text { iv, } \\
\text { frusemide } 100 \mathrm{mg} \text { iv }\end{array}$ & Aspirin $0.5 \mathrm{~g}+1.0 \mathrm{~g}$ oral & $\begin{array}{l}\text { Frusemide } 40 \mathrm{mg} \text { iv, } \\
\text { aspirin } 2.0 \mathrm{mg} \text { oral }\end{array}$ \\
\hline J & Congestive heart failure & $\begin{array}{l}\text { Morphine } 5 \mathrm{mg} \text { iv, } \\
\text { frusemide } 20 \mathrm{mg} \text { iv }\end{array}$ & $\mathbf{0}$ & Frusemide $\mathbf{8 0} \mathbf{~ m g}$ oral \\
\hline
\end{tabular}



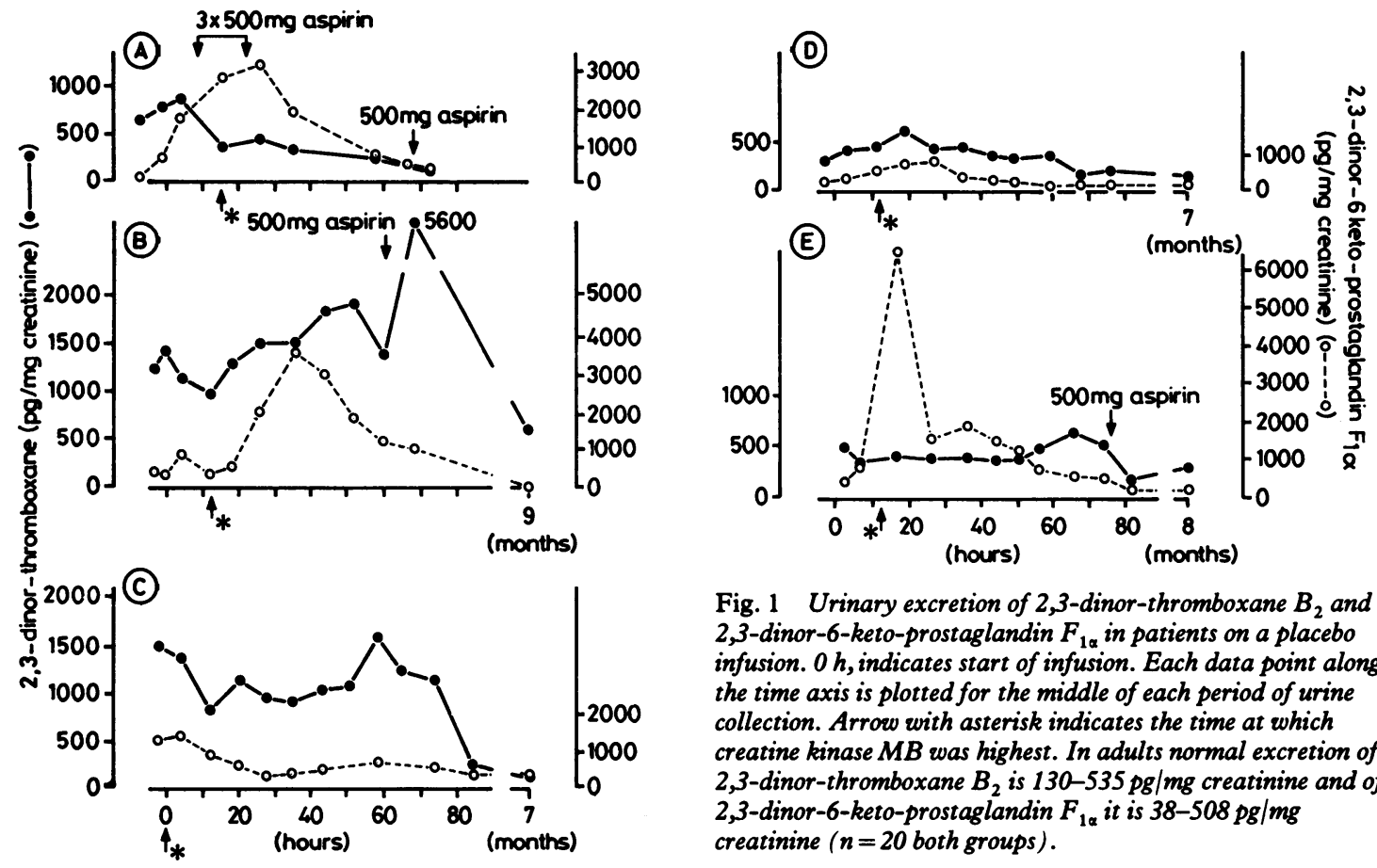

Fig. 1 Urinary excretion of 2,3-dinor-thromboxane $B_{2}$ and 2,3-dinor-6-keto-prostaglandin $F_{1 \alpha}$ in patients on a placebo infusion. $0 \mathrm{~h}$, indicates start of infusion. Each data point along the time axis is plotted for the middle of each period of urine collection. Arrow with asterisk indicates the time at which creatine kinase $M B$ was highest. In adults normal excretion of 2,3-dinor-thromboxane $B_{2}$ is $130-535 \mathrm{pg} / \mathrm{mg}$ creatinine and of 2,3-dinor-6-keto-prostaglandin $F_{1 \alpha}$ it is 38-508 pg/mg creatinine ( $n=20$ both groups).
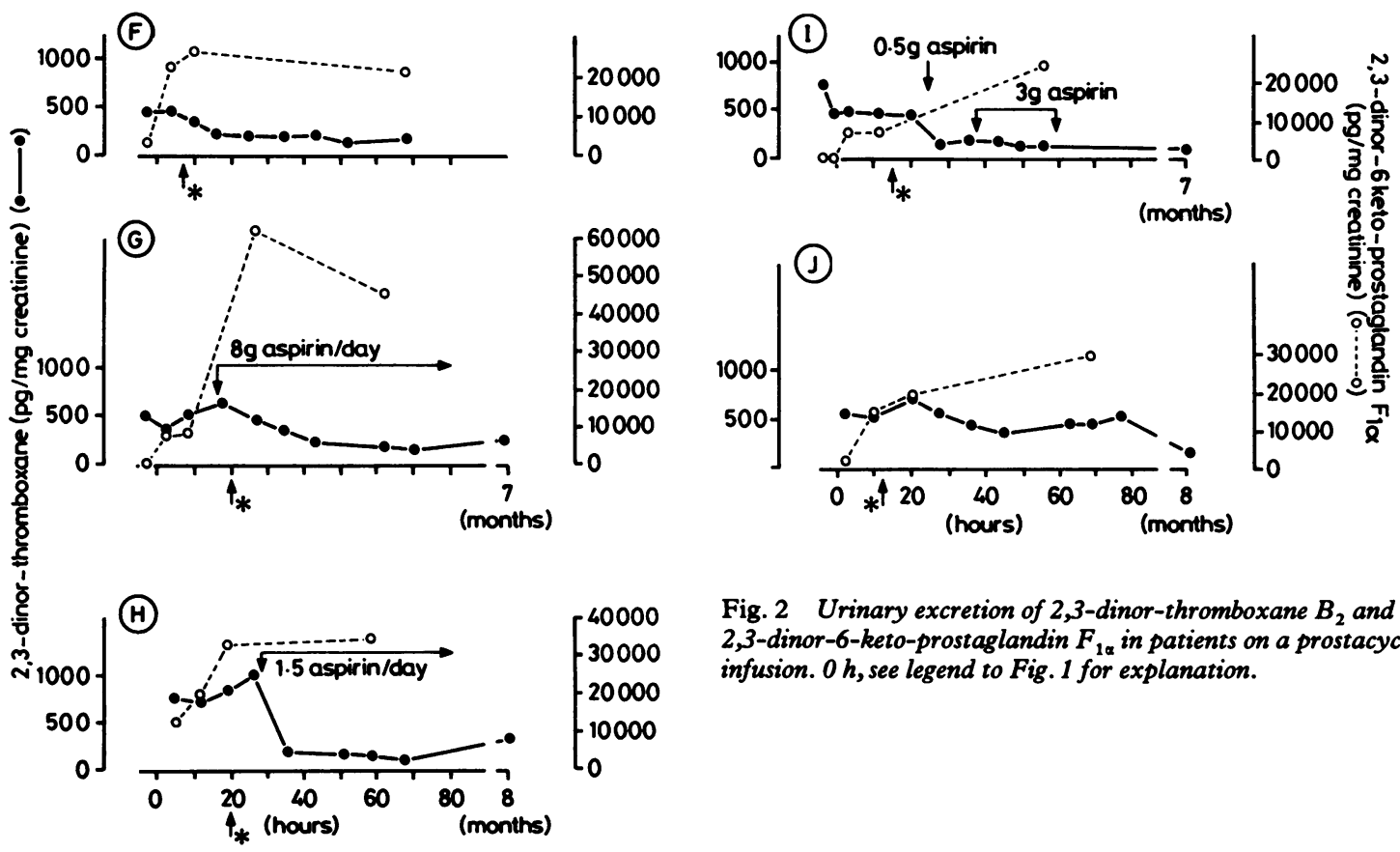

Fig. 2 Urinary excretion of 2,3-dinor-thromboxane $B_{2}$ and 2,3-dinor-6-keto-prostaglandin $F_{1 \alpha}$ in patients on a prostacyclin infusion. $0 \mathrm{~h}$, see legend to Fig. 1 for explanation. 
prostaglandin $F_{1 \alpha}$ was 636 and $86 \mathrm{pg} / \mathrm{mg}$ creatinine respectively.

Patient C-Excretion of 2,3-dinor-thromboxane $B_{2}$ in all urine samples but the last one was higher than that seen in normal healthy males. The peak value, 54-62 hours after the start of infusion, coincided with three episodes of angina pectoris. Seven months later excretion of 2,3-dinor-thromboxane $B_{2}$ was $143 \mathrm{pg} / \mathrm{mg}$ creatinine. In this patient excretion of 2,3-dinor-6-keto-prostaglandin $F_{1 \alpha}$ reached a peak $(1405 \mathrm{pg} / \mathrm{mg}$ creatinine) shortly after the maximal creatine kinase $M B$ value. Seven months later the excretion was $358 \mathrm{pg} / \mathrm{mg}$ creatinine.

Patient $D$-The urinary excretion of 2,3-dinor-thromboxane $B_{2}$ in this patient was initially $302 \mathrm{pg} / \mathrm{mg}$ creatinine and increased to twice this value around $10 \mathrm{~h}$ after the maximum creatine kinase $M B$ value. Excretion seven months later was $192 \mathrm{pg} / \mathrm{mg}$ creatinine. Urinary excretion of 2,3-dinor-6-keto-prostaglandin $F_{1 \alpha}$ was initially within normal limits for healthy males. It then increased to a maximum of $755 \mathrm{pg} / \mathrm{mg}$ creatinine. Seven months later excretion was $119 \mathrm{pg} / \mathrm{mg}$ creatinine.

Patient E-Urinary excretion of 2,3-dinorthromboxane $B_{2}$ was within the normal range until about 50 hours after creatine kinase MB concentration reached a maximum, then it increased to a peak of $650 \mathrm{pg} / \mathrm{mg}$ creatinine. A dose of aspirin $(500 \mathrm{mg})$ reduced the urinary excretion rate of 2,3-dinor-thromboxane $\mathbf{B}_{2}$ by about $70 \%$. Eight months later urinary excretion was $318 \mathrm{pg} / \mathrm{mg}$ creatinine. The initial urinary excretion rate of 2,3-dinor-6-keto-prostaglandin $F_{1 \alpha}$ was within the normal range but it then increased abruptly to a maximum of $6348 \mathrm{pg} / \mathrm{mg}$ creatinine. This abrupt increase was not associated with any obvious clinical symptom. Eight months later urinary excretion was $240 \mathrm{pg} / \mathrm{mg}$ creatinine.

PROSTACYCLIN (EPOPROSTENOL) INFUSION After the start of prostacyclin infusion the excretion of 2,3-dinor-6-keto-prostaglandin $\mathrm{F}_{1 \alpha}$ increased to around $30000 \mathrm{pg} / \mathrm{mg}$ creatinine.

Patient $F$-In the first urine samples the urinary excretion of 2,3-dinor-thromboxane $B_{2}$ was 459 and $472 \mathrm{pg} / \mathrm{mg}$ creatinine and thereafter the excretion fell to around $200 \mathrm{pg} / \mathrm{mg}$ creatinine. Urinary excretion of 2,3-dinor-6-keto-prostaglandin $F_{1 \alpha}$ was increased in the first urine sample, probably because the infusion was started 0.5 hour before the collection of the first urine sample was completed. As expected excretion increased even more during the infusion.

Patient G-Urinary excretion of 2,3-dinorthromboxane $B_{2}$ was initially somewhat raised (peak value $630 \mathrm{pg} / \mathrm{mg}$ creatinine). The development of a severe pericarditis (at about 20 hours) required treatment with $8 \mathrm{~g}$ of aspirin daily combined with injection of $100 \mathrm{mg}$ hydrocortisone. Despite this large dose of aspirin urinary excretion of 2,3-dinor-thromboxane $B_{2}$ only decreased slowly to about $30 \%$ of the maximum level. Seven months later the excretion of 2,3-dinor-thromboxane $B_{2}$ was $249 \mathrm{pg} / \mathrm{mg}$ creatinine.

Patient $H$-During the first day of prostacyclin infusion the urinary excretion rate of 2,3-dinorthromboxane $B_{2}$ was clearly higher than the excretion rate in normal healthy males. Twenty eight hours after the start of the infusion the patient was started on $1.5 \mathrm{~g}$ aspirin daily for pericarditis. An abrupt reduction in excretion (by about $80 \%$ ) followed. Eight months later excretion of the thromboxane metabolite was $320 \mathrm{pg} / \mathrm{mg}$ creatinine.

Patient I-Urinary excretion of 2,3-dinorthromboxane $\mathbf{B}_{2}$ in the initial sample was clearly higher $(755 \mathrm{pg} / \mathrm{mg}$ creatinine) than that in normal healthy males. The patient received $500 \mathrm{mg}$ aspirin at about 25 hours, and this reduced urinary excretion of 2,3-dinor-thromboxane $B_{2}$ by $50-60 \%$. Later the patient was given more aspirin ( $3 \mathrm{~g}$ in total) without any further reduction of the excretion of 2,3-dinor-thromboxane $B_{2}$. The excretion of 2,3-dinor-thromboxane $B_{2}$ seven months later was $115 \mathrm{pg} / \mathrm{mg}$ creatinine.

Patient $\boldsymbol{f}$-The urinary excretion of 2,3-dinor-thromboxane $B_{2}$ was slightly higher than

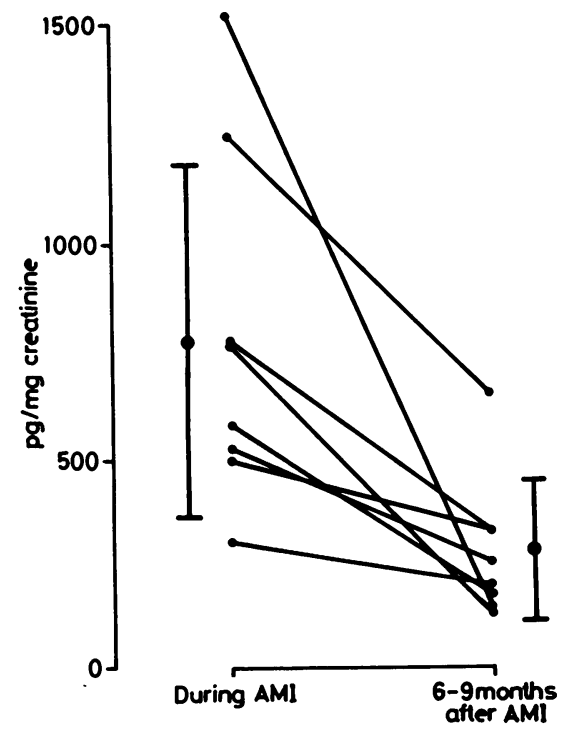

Fig. 3 Urinary excretion of 2,3-dinor-thromboxane $B_{2}$ in the first sample collected after acute myocardial infarction (AMI) and in a sample collected 6-9 months later in eight individuals. Individual values are means (SD). 
normal for most of the study. Eight months later the excretion of 2,3-dinor-thromboxane $B_{2}$ was $173 \mathrm{pg} / \mathrm{mg}$ creatinine.

\section{STATISTICAL EVALUATION}

We compared the initial and follow up values on the excretion of 2,3-dinor-thromboxane $B_{2}$ in the eight cases in which we were able to collect follow up samples (Fig. 3). The mean initial excretion was 771 (410) $\mathrm{pg} / \mathrm{mg}$ creatinine (mean (SD)) and the follow up excretion was 268 (167) $\mathrm{pg} / \mathrm{mg}$ creatinine (mean (SD)). Student's $t$ test for paired samples showed a highly significant difference $(p<0.01)$ between the initial and follow up excretion.

\section{Discussion}

We found a prolonged increase in the in vivo synthesis of thromboxane and prostacyclin during the acute phase of myocardial infarction. This suggests that these substances may be involved in the pathophysiology of acute myocardial infarction.

In all patients except case $F$ excretion of 2,3-dinor-thromboxane $B_{2}$ was higher than normal during at least part of the study period. Since there is little variation (SD 10-23\%) in the excretion of 2,3-dinor-thromboxane $B_{2}$ in a normal individual over weeks and months, ${ }^{16}$ we believe that the finding that maximum increases seen during the study were 2-11 times higher than those found 7-9 months later is more important than the general rise in excretion. There was also a highly significant difference between the excretion in the very first urine sample, which was collected before any treatment was started, and in that obtained 7-9 months later. Moreover the excretion in one and the same individual during the first $\mathbf{8 0}$ hours was very variable; the ratio between the highest and lowest values ranged from about 1.5:1 to 3.5:1 (values for case $A$ and after aspirin are not included). Thus both the level of and the variability of the excretion of 2,3-dinor-thromboxane $B_{2}$ strongly suggest the involvement of thromboxane in the pathogenesis of acute myocardial infarction.

Excretion of 2,3-dinor-6-keto-prostaglandin $F_{1 \alpha}$ in four of the cases without prostacyclin infusion was initially within the normal range. Thereafter the excretion increased, reaching a peak 2-20 hours after the maximum creatine kinase MB value. Excretion of 2,3-dinor-6-keto-prostaglandin $F_{1 \alpha}$ varies in healthy individuals (intra-individual variation $16-31 \% \mathrm{SD}^{16}$ ) and increases considerably during physical exercise. ${ }^{14}$ Despite the fact that our patients remained in bed, the maximum concentrations seen in cases $\mathrm{A}, \mathrm{B}, \mathrm{C}$, and $\mathrm{E}$ were far above (or in case $\mathrm{D}$, close to), concentrations found in normal individuals during strenuous exercise. In all cases (A-J) excretion of 2,3-dinor-6-ketoprostaglandin $F_{1 \alpha}$ seven to nine months later was within the range seen in normal individuals. Thus prostacyclin synthesis in vivo is increased during an acute myocardial infarction. Synthesis is greatest soon after maximal disintegration of myocardial tissue, as indicated by the appearance of creatine kinase $M B$ in the circulation.

Excretion of 2,3-dinor-6-keto-prostaglandin $F_{1 \alpha}$ before infusion of prostacyclin was within normal limits and increased to about $30000 \mathrm{pg} / \mathrm{mg}$ creatinine during infusion. The infusion had no obvious immediate effect on the excretion of the thromboxane metabolite. These data seem to contradict the idea that exogenous prostacyclin will reduce in vivo thromboxane synthesis.

Three individuals in each group were given aspirin during the study. Only three of them, E, H, and $I$, showed an abrupt reduction in 2,3-dinorthromboxane $\mathrm{B}_{2}$ excretion (by $65 \%, 82 \%$, and $65 \%$ respectively). These values are similar to or only slightly higher than those seen in normal individuals after $500 \mathrm{mg}$ of aspirin. The effect of aspirin on the excretion of 2,3-dinor-thromboxane $B_{2}$ in cases $A$, $B$, and $G$, however, is distinctly different from that seen in normal individuals. ${ }^{1316}$ In case $A$ a dose of $3 \times 500 \mathrm{mg}$ aspirin caused a $55 \%$ decrease in urinary 2,3-dinor-thromboxane $B_{2}$ from 880 to about $378 \mathrm{pg} / \mathrm{mg}$ creatinine. A further $500 \mathrm{mg}$ aspirin given at $69 \mathrm{~h}$ caused another reduction from 205 to $124 \mathrm{pg} / \mathrm{mg}$ creatinine. Patient $B$ was given $500 \mathrm{mg}$ aspirin at 61 hours when symptoms of what later turned out to be a post-myocardial infarction syndrome first appeared. The urine sample collected after this showed an enormous increase in the excretion of 2,3-dinor-thromboxane $B_{2}$. Patient $G$ developed symptoms of pericarditis around 20 hours after the start of infusion and daily doses of $8 \mathrm{~g}$ aspirin were given. Despite this large dose excretion of 2,3-dinor-thromboxane $B_{2}$ declined only gradually to around $150 \mathrm{pg} / \mathrm{mg}$ creatinine. Aspirin has less effect on thromboxane synthesis during acute myocardial infarction (that is when thromboxane synthesis seems to be raised and labile) than it does in healthy individuals.

Our data strongly indicate that synthesis of thromboxane is increased and variable for several days after acute myocardial infarction. This probably reflects a generalised increase in platelet aggregability but we cannot rule out the possibility of an increase in thromboxane synthesis when the coronary vessel becomes occluded. We can only speculate on the reasons for a very high synthesis of prostacyclin, which peaked after maximum creatine kinase $\mathrm{MB}$ release, but this finding could indicate 
548

that most of the increase in endogenous prostacyclin synthesis is the result of tissue necrosis or even repair. The excretion data collected after administration of prostacyclin and aspirin raise several new questions about the prevention of acute myocardial infarction and reduction of infarct size. ${ }^{19}$ The actions of aspirin and or other thromboxane synthetase inhibitors on the synthesis of thromboxane $A_{2}$ under pathological conditions clearly cannot be forecast from results obtained under normal conditions. Studies are continuing.

This study was supported by grants from the Swedish National Association against Heart and Chest Diseases, the Swedish Medical Research Council, and The Upjohn Company.

\section{References}

1 Schwartz CJ. Thrombosis in the pathogenesis of sudden cardiac death and myocardial infarction. In: Oates $\mathrm{J}$, ed. Advances in prostaglandin, thromboxane and leukotriene research vol 10; Prostaglandins and the cardiovascular system. New York: Raven Press, 1982: 1-14.

2 Granström E, Diczfalusy U, Hamberg M, Hansson G, Malmsten C, Samuelsson B. Thromboxane $\mathrm{A}_{2}$ : biosynthesis and effects on platelets. In: Oates J, ed. Advances in prostaglandin, thromboxane and leukotriene research vol 10; Prostaglandin and the cardiovascular system. New York: Raven Press, 1982: 15-58.

3 Dusting GJ, Moncada S, Vane JR. Prostacyclin: Its biosynthesis, actions and clinical potential. In: Oates J, ed. Advances in prostaglandin, thromboxane and leukotriene research vol 10; Prostaglandin and the cardiovascular system. New York: Raven Press, 1982: 59-106.

4 Thorngren M, Shafi S, Born GVR. Thromboxane $A_{2}$ in skin-bleeding-time blood and in clotted venous blood before and after administration of acetylsalicyclic acid. Lancet 1983; i: 1075-8.

5 Blair IA, Barrow SE, Waddell KA, Lewis PJ, Dollery CT. Prostacyclin is not a circulating hormone in man. Prostaglandins 1982; 23: 579-89.

6 Hutton RA, Chow FPR. Radioimmunoassay of 6-keto-PGF ${ }_{1 \alpha}$ in plasma: an artefact introduced by
Henriksson, Wennmalm, Edhag, Vesterqvist, Green

plasma extraction. Br $\mathcal{F}$ Haematol 1982; 51: 327.

7 FitzGerald GA, Brash AR, Falardeau P, Oates JA. Estimated rate of prostacyclin secretion into the circulation of normal man. $f$ Clin Invest 1981; 68: 1272-6.

8 Butt RW, Buchanan MR. Basal 6-keto-PGF ${ }_{1 \alpha}$ levels: influence of sampling techniques. Thromb Res 1983; 29: 469-70.

9 Roberts LJ, Sweetman BJ, Oates JA. Metabolism of thromboxane $\mathbf{B}_{\mathbf{2}}$ in man. Identification of twenty urinary metabolites. F Biol Chem 1981; 256: 8384-93.

10 Rosenkranz B, Fischer C, Weimer KE, Frölich JC. Metabolism of prostacyclin and 6-keto-prostaglandin $F_{1 \alpha}$ in man. I Biol Chem 1980; 255: 10194-8.

11 Falardeau P, Oates JA, Brash A. Quantitative analysis of two dinor urinary metabolites of prostaglandin $\mathrm{I}_{2}$. Anal Biochem 1981; 115: 359-67.

12 Maas RL, Taber DF, Jackson Roberts L II. Quantitative assay of urinary 2,3-dinor-thromboxane $B_{2}$ by GC-MS. Methods Enzymol 1982; 86: 592-603.

13 Vesterqvist $O$, Green $K$, Lincoln FH, Sebek OK. Development of a GC-MS method for quantitation of 2,3-dinor- $\mathrm{TxB}_{2}$ and determinations of the daily urinary excretion rates in healthy humans. Thromb Res 1983; 33: 39-49.

14 Vesterqvist O, Green K. Development of a GC-MS method for quantitation of 2,3-dinor-6-keto-PGF ${ }_{1 \alpha}$ and determination of the urinary excretion rates in healthy humans under normal conditions and following drugs. Prostaglandins 1984; 28: 139-53.

15 Vesterqvist $O$, Green $K$. Urinary excretion of 2,3-dinor-thromboxane $B_{2}$ in man under normal conditions, following drugs and during some pathological conditions. Prostaglandins 1984; 27: 627-44.

16 Vesterqvist $O$. Rapid recovery of in vivo prostacyclin formation after inhibition by aspirin-evidence from measurements of the major urinary metabolite of prostacyclin by GC-MS. Eur $f$ Clin Pharm 1986; 30: 69-73.

17 Vesterqvist O, Edhag O, Green K, Henriksson P. In vivo production of thromboxane in acute human myocardial infarction: a preliminary study. Thromb Res 1985; 37: 459-64.

18 Henriksson P, Edhag O, Wennmalm Å. Prostacyclin infusion in patients with acute myocardial infarction. Br Heart $f$ 1985; 53: 173-9.

19 Kübler W, Doorey A. Reduction of infarct size: an attractive concept: useful - or possible—in humans? $\mathrm{Br}$ Heart $\mathcal{F}$ 1985; 53: 5-8. 